\title{
The Comparison of the Efficacy and Safety of Intralesional Triamcinolone Acetonide and Methotrexate Injections for the Treatment of Fingernail Psoriasis
}

\author{
El Tırnak Psöriasisinin Tedavisinde Intralezyonel Triamsinolon Asetonit ve Metotreksat \\ Enjeksiyonlarının Etkinlik ve Güvenilirliğinin Karşılaștırılması
}

\author{
(D) Pelin Üstüner, (D) Ali Balevi, (1) Mustafa Özdemir \\ Istanbul Medipol University Faculty of Medicine, Department of Dermatology, Istanbul, Turkey
}

\section{Abstract}

Objectives: Studies have demonstrated that the clinical efficacy and remission duration of intralesional corticosteroids in nail psoriasis are highly variable. Moreover, good clinical results have been reported after methotrexate injection in a case study with nail psoriasis. This study aimed to investigate the efficacy and safety of intralesional injection of triamcinolone acetonide and methotrexate in patients with fingernail psoriasis.

Materials and Methods: Thirty-two patients diagnosed with fingernail psoriasis with at least three affected nails were included. Diluted triamcinolone acetonide, methotrexate and serum physiologic solution were randomly injected into three different fingernails having similar nail area psoriasis severity index (NAPSI) scores for four sessions. We compared the signs of nail matrix and nail bed involvement. The severity of fingernail psoriasis was investigated using NAPSI and modified NAPSI.

Results: The responses evaluated by the NAPSI scores were similar in nails treated with methotrexate and triamcinolone acetonide. The improvement of the signs of nail matrix involvement was significantly higher in nails treated with methotrexate, but the improvement of the signs of nail bed involvement was similar in all groups. The improvement of onycholysis was significant only in nails treated with triamcinolone. On the other hand, the improvement of pitting and leukonychia were significant only in nails treated with methotrexate.

Conclusion: Methotrexate injection might be a better treatment choice for fingernail psoriasis with the signs of nail matrix involvement and triamcinolone acetonide injection for the fingernail psoriasis with the signs of nail bed involvement.

Key Words: Methotrexate, Psoriasis, Steroid

\section{Öz}

Amaç: Çalışmalar tırnak psöriasisinde intralezyonel kortikosteroidlerin klinik etkinliği ve remisyon süresinin oldukça değişken olduğunu göstermektedir. Ayrıca, tırnak psöriasisli bir olgu raporunda metotreksat enjeksiyonundan sonra iyi klinik sonuçlar bildirilmiştir. Bu çalışma el tırnak psöriasisli hastalarda intralezyonel triamsinolon asetonit ve metotreksat enjeksiyonunun etkinlik ve güvenilirliğini araştırmayı amaçlamaktadır.

Gereç ve Yöntem: En az üç tırnak tutulumu olan el tırnaklarında psöriasis tanısı olan otuz iki hasta çalışmaya dahil edildi. Benzer tırnak alan psoriasis şiddet indeks (NAPSI) skorları olan üç farklı el tırnağına sulandırılmış triamsinolon asetonit, metotreksat ve serum fizyolojik dört seans süresince rastgele enjekte edildi. Tırnak matriks ve tırnak yatak tutulum bulgularını karşılaştırdık. El tırnaklarının psoriasis şiddeti NAPSI ve modifiye NAPSI kullanılarak araştırıldı.

Bulgular: Metotreksat ve triamsinolon asetonit ile tedavi alan tırnaklarda NAPSI skorları ile değerlendirilen yanıtlar benzer idi. Tırnak matriks tutulumu bulgularının iyileşmesi metotreksat ile tedavi edilen tırnaklarda anlamlı oranda daha fazla idi, ancak tırnak yatak tutulumu bulgularının iyileşmesi tüm gruplarda benzer idi. Onikolizin iyileşmesi yanlızca triamsinolon ile tedavi gören tırnaklarda anlamlı idi. Diğer yandan, pitting ve lökonişinin iyileşmeleri yanlızca metotreksat tedavisi alan tırnaklarda anlamlı idi.

Sonuç: Metotreksat enjeksiyonu tırnak matriks tutulumu bulguları olan el tırnak psöriasisinde ve triamsinolon asetonit enjeksiyonu ise tırnak yatak tutulumu bulguları olan el tırnak psöriasisinde daha iyi bir tedavi seçeneği olabilir.

Anahtar Kelimeler: Metotreksat, Psöriasis, Steroid

Address for Correspondence/Yazışma Adresi: Pelin Üstüner MD,

İstanbul Medipol University Faculty of Medicine, Department of Dermatology, İstanbul, Turkey

Phone: +90 2124447044 E-mail: pelindogaustuner@gmail.com ORCID ID: orcid.org/0000-0002-7885-0537

Received/Geliş Tarihi: 04.01.2018 Accepted/Kabul Tarihi: 27.04.2018

๑Copyright 2018 Ankara University Faculty of Medicine

Journal of Ankara University Faculty of Medicine is published by Galenos Publishing House.

All content are under CC BY-NC-ND license. 


\section{Introduction}

Patients with psoriasis may present with pitting, leukonychia, red lunula (erythema) and onychorrhexis in nail matrix and oil spots or salmon patches that show yellowish or reddish discoloration of nail plates, splinter hemorrhage, onycholysis and subungual hyperkeratosis in nail bed (1). Almost 50\% of patients with psoriasis vulgaris and up to $80 \%$ of patients with psoriatic arthritis are afflicted with nail lesions. Most psoriatic nail disease occurs in patients with clinically evident psoriasis; it only occurs in less than $5 \%$ of patients with no other cutaneous findings of psoriasis (1). In clinical studies, different scoring methods such as nail area psoriasis severity index (NAPSI), target-NAPSI and modified-NAPSI have been used (1). To date, topical and intralesional intralesional corticosteroids, topical vitamin D derivatives such as calcipotriol, tacalcitol, calcitriol, topical tazarotene, anthralin, 5-fluorouracil and indigo naturalis oil extract have been used as topical treatments for nail psoriasis (2). As the nail psoriasis is more resistant to conventional anti-psoriatic drugs than other parts of skin psoriasis, there is no established treatment protocol nor satisfied therapy (1). There are only few randomized comparative clinical studies on intralesional nail treatments due to the difficulty of nail matrix injection methods (3-6). Among intralesional treatment options, triamcinolone acetonide (TA) is one of the most commonly used agents; however, the intralesional application has certain disadvantages such as pain (4). The clinical efficacy and remission duration of intralesional TA are highly variable (3-8). The subcutaneous injection of methotrexate has also been proven to be effective for the treatment of nail psoriasis (9). In a 26-year old female diagnosed with nail psoriasis that was resistant to conventional treatments, a weekly injection of $2.5 \mathrm{mg}$ methotrexate into the nail matrix for six sessions was reported to achieve an almost complete clinical improvement of subungual hyperkeratosis and pitting (10). To our knowledge, the efficacy of intralesional methotrexate has only been reported in one case study including 30 psoriatic fingernails of four patients; however, the comparison of the efficacy of intralesional TA and methotrexate for the treatment of fingernail psoriasis has not been reported (11). In this study, we aimed to fill this gap in the literature as well as examine the signs of nail matrix and nail bed involvements separately after both treatments. This can also guide clinicians for the intralesional treatment choice in patients with nail matrix or nail bed involvement or both.

\section{Materials and Methods}

We initially planned to conduct the study with 35 patients aged 18-60 years diagnosed with nail psoriasis with at least three affected fingernails who had not been taking any previous topical or systemic anti-psoriasis drugs for three months.
However, three patients refused to undergo treatment; thus, the total number of patients included in the study was 32 . The study was approved by the local ethics committee (66291034604.01.01-E.2043), and all the patients provided written informed consent. The written informed consent was obtained from all the patients before the commencement of the study. Exclusion criteria included fungal infection in all patients via direct microscopic examination and fungal culture. The patients under systemic treatment, those with occupations involving a continuous exogenous exposure to irritants such as hair dressers, housekeepers and cooks, those with systemic diseases such as diabetes mellitus, those that had undergone phototherapy, systemic or topical treatments for psoriasis within the last three months and those who had allergy to lidocaine or prilocaine were also excluded from the study. Nail matrix abnormalities such as pitting, leukonychia, red lunula, onychorrhexis, and nail bed abnormalities including splinter hemorrhage, onycholysis, subungual hyperkeratosis, oil spots and salmon patches were separately recorded. The type and duration of psoriasis, presence of arthritis, previous anti-psoriatic nail treatments, the signs of nail matrix and nail bed involvements were also recorded. We compared the rate of these signs both before the study and one month after the last injection session. Diluted TA (Sinacort ${ }^{\circledR}$ ) in $10 \mathrm{mg} / \mathrm{dL}$, methotrexate $\left(\right.$ Metoart $\left.^{\circledR}\right)$ in 10 $\mathrm{mg} / \mathrm{dL}$ and serum physiologic (SP) solution (0.9\% solution of sodium chloride and water) were randomly injected either into the distal nail folds or into the nail matrices or both of three different fingernails having similar NAPSI scores in each patient. Before the injection, we applied topical lidocaine (Emla) under occlusion or digital nerve anesthesia and cooling with ice cubes for the patients that did not tolerate pain. We made a total of four injections of $0.1 \mathrm{~mL}$ into four different possible points; two into the proximal nail fold at a tangential plane and advanced to the nail bed through the lateral and medial nail matrices and two in distal medial and lateral nail folds through the distal nail bed until loss of resistance was felt (Figure 1) $(10,11)$. Intralesional TA injection was performed either into the nail matrix by using modified De Berker's technique that has been shown to improve both nail matrix and nail bed disease or into the nail beds through the distal nail folds $(12,13)$. Besides, methotrexate was also injected into either the nail bed or the nail matrix or both according to the presence of the subject's signs of nail involvements. The injection into the proximal nail folds was performed as previously performed by Daulatabad et al. (11) in a previous study. An insulin syringe with 30G needle was used to reduce pain. Four injections were made at three-week intervals. We photographed all the fingernails by a standard camera before the study, at each session and one month after the last injection. Nail injections and evaluation of nail psoriasis severity were undertaken by two independent dermatologists (P.U., A.B.). The severity of nail psoriasis was 
investigated by modified-NAPSI scores before the study and at each visit with a blinded evaluation $(1,14-16)$. We classified the clinical improvement into four categories depending on the change in the modified NAPSI scores as follows: mild improvement $(<25 \%$ decrease), moderate improvement (25$49 \%$ decrease), marked or high improvement (50-75\% decrease) and almost complete improvement ( $>75 \%$ decrease). Based on the clinician's assessment, the clinical response of the patients was classified as very bad (<30\% improvement), bad (30-50\% improvement), good (50-75\% improvement) and very good ( $>75 \%$ improvement). Patient satisfaction was scored on a fourpoint scale from 1 least satisfied to 4 very satisfied. The pain intensity during injection via Visual Analog scale (VAS) and the adverse effects were recorded. After a six-month follow-up, at least $50 \%$ or more increase in the modified-NAPSI scores was considered as clinical relapse.

\section{Statistical Analysis}

The Number Cruncher Statistical System (NCSS 2007, Kaysville, Utah, USA) was used for statistical analysis. In the examination of the study data, in addition to qualitative statistical methods (mean, standard deviation, median, frequency, rate, minimum, and maximum), the Kruskal-Wallis test was used for the comparison of three or more groups with abnormal distribution and the Mann-Whitney U Test was used for paired comparisons. The Pearson chi-square, Fisher-FreemanHalton and McNemar tests were used for the comparisons of quantitative data. The Wilcoxon signed-rank test was conducted for the intra-group comparison of quantitative data

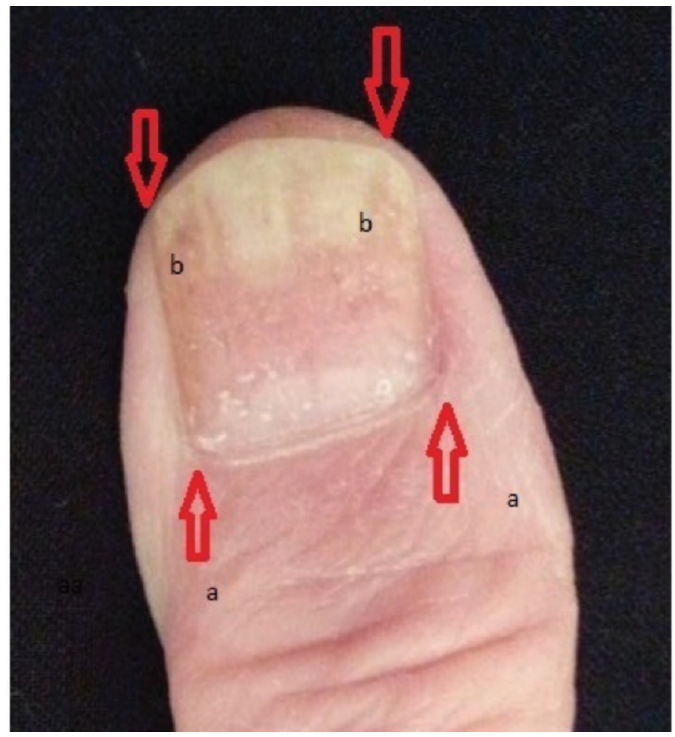

Figure 1: The nail injection technique via an insulin syringe a) $\uparrow$ (upper arrows) Two injection points for the nail matrix (into the proximal nail fold at a tangential plane and advanced to the nail bed through the lateral and medial nail matrices) b) $\downarrow$ (down arrows) Two injection points for the nail bed (into the distal medial and lateral nail folds through the distal nail bed) $(10,11)$ with abnormal distribution. Furthermore, the Friedman test was undertaken for the evaluation of 3 or more follow-up data of the variables with abnormal distribution. The significance was evaluated at $p<0.05$.

\section{Results}

The study was conducted with a total of 96 nails with psoriasis in 32 patients, 15 females (46.9\%) and 17 males (53.1\%), diagnosed with fingernail psoriasis and admitted to our university dermatology department between January 2015 and January 2017. The patients were aged 24 and 57 years with a mean of $41.37 \pm 9.31$ years. The clinical type of psoriasis was plaque-type in $18.8 \%$ of patients $(n=6)$, localized plaque-type in $28.1 \%(n=9)$, palmoplantar hyperkeratotic-type in $18.8 \%(n=6)$, palmoplantar pustular-type in $31.3 \%(n=10)$ and scalp psoriasis in $3.1 \%(n=1)$. Arthritis was present only in 5 patients $(15.6 \%)$.

\section{Modified-nail Area Psoriasis Severity Index Scores}

The modified-NAPSI scores were similar in methotrexate and TA treatments at months $0(p=0.860)$ and $4(p=0.126)$. At month 4 , the decrease in the modified-NAPSI scores was statistically significant for both groups ( $p=0.001$ and 0.001 , respectively). At month 4 , the increase in the modified-NAPSI scores of the nails treated with SP was also significant ( $p=0.039)$.

\section{Signs of Nail Bed Involvement}

The signs of nail bed involvement were statistically similar in different treatment groups at months $0(p=0.924)$ and 4 $(p=0.171)$ (Table 1). At month 4 , the ratio of the signs of nail bed involvement did not statistically significantly change in methotrexate $(p=0.250)$, TA ( $p=0.063)$ and SP $(p=1.000)$ groups. At month 4 , subungual hyperkeratosis $(p=0.003)$ and onycholysis were significantly lower after TA treatment than SP at month 4 (Table 1). At month 4, onycholysis statistically significantly decreased only in nails treated with TA (Figure 2a and 2b) $(p=0.039) \quad$ (Table 1). Subungual hyperkeratosis statistically significantly decreased in both TA $(p=0.004)$ and methotrexate ( $p=0.016)$ groups at month 4 .

\section{Signs of Nail Matrix Involvement}

The ratios of the signs of nail matrix involvement were statistically similar in different treatment groups at month 0 $(p=0.869)$. However, at month 4 , they were significantly lower in nails treated with methotrexate than those treated with TA $(p=0.030)$ and SP $(p=0.003)$. The ratios of nail matrix signs were similar at month 4 for both TA and SP treatments $(p=0.613)$. At month 4 , a statistically significantly decrease was only seen in nails treated with methotrexate $(p=0.008)$ (Table 2). At month 4 , the percentages of leukonychia and onychorrhexis $(p=0.019)$ were significantly lower in nails treated with methotrexate than those treated with SP. At month 4, a statistically significant 
decrease in pitting $(p=0.001)$ and leukonychia $(p=0.002)$ was only seen in the nails treated with methotrexate (Figure $2 \mathrm{c}$ and 2d) (Table 2). At month 4, red lunula and onychorrhexis statistically significantly decreased in nails treated with methotrexate ( $p=0.001, p=0.008$ respectively) and TA ( $p=0.001$, $p=0.016$ respectively).

\section{Clinician's Assessment and Patient Satisfaction}

The ratio of good clinical response was significantly higher in nails treated with methotrexate than those treated with SP at month $1(p=0.001)$ (Table 3$)$. The patient satisfaction scores significantly varied depending on the treatment groups of methotrexate and TA at months 1 and $4(p=0.001, p=0.001$ respectively). At month 1 , the ratio of 'very satisfied' was

Table 1: The assessment of the signs of nail bed involvement according to different treatments

\begin{tabular}{|c|c|c|c|c|c|}
\hline & & \multicolumn{3}{|c|}{ Treatment } & \multirow[t]{2}{*}{$\mathbf{p}$} \\
\hline & & $\begin{array}{l}\text { Mtx } \\
(n=32)\end{array}$ & $\begin{array}{l}\text { TA } \\
(n=32)\end{array}$ & $\begin{array}{l}S P \\
(n=32)\end{array}$ & \\
\hline \multicolumn{6}{|c|}{ Sign of nail bed involvement } \\
\hline \multirow[t]{2}{*}{ Month 0} & Absent & $3(9.4)$ & $5(15.6)$ & $4(12.5)$ & ${ }^{\mathrm{d}} 0.924$ \\
\hline & Present & $29(90.6)$ & $27(84.4)$ & $28(87.5)$ & \\
\hline \multirow[t]{3}{*}{ Month 4} & Absent & $6(18.8)$ & $10(31.3)$ & $4(12.5)$ & ${ }^{\mathrm{c}} 0.171$ \\
\hline & Present & $26(81.3)$ & $22(68.8)$ & $28(87.5)$ & \\
\hline & ${ }^{\mathrm{e}} \mathrm{p}$ & 0.250 & 0.063 & 1.000 & \\
\hline \multicolumn{6}{|c|}{ Oil/salmon patch } \\
\hline \multirow[t]{2}{*}{ Month 0} & Absent & $10(31.3)$ & $8(25.0)$ & $9(28.1)$ & ${ }^{\mathrm{c}} 0.857$ \\
\hline & Present & $22(68.8)$ & $24(75.0)$ & $23(71.9)$ & \\
\hline \multirow[t]{3}{*}{ Month 4} & Absent & $17(53.1)$ & $21(65.6)$ & $9(28.1)$ & ${ }^{\mathrm{c}} 0.009^{* *}$ \\
\hline & Present & $15(46.9)$ & $11(34.4)$ & $23(71.9)$ & \\
\hline & ${ }^{\mathrm{e}} \mathbf{p}$ & $0.016^{*}$ & $0.001^{* *}$ & 1.000 & \\
\hline \multicolumn{6}{|c|}{ Splinter hemorrhage } \\
\hline \multirow[t]{2}{*}{ Month 0} & Absent & $12(37.5)$ & $12(37.5)$ & $14(43.8)$ & ${ }^{\mathrm{c}} 0.840$ \\
\hline & Present & $20(62.5)$ & $20(62.5)$ & $18(56.3)$ & \\
\hline \multirow[t]{3}{*}{ Month 4} & Absent & $21(65.6)$ & $24(75.0)$ & $13(40.6)$ & ${ }^{\mathrm{c}} 0.015^{*}$ \\
\hline & Present & $11(34.4)$ & $8(25.0)$ & $19(59.4)$ & \\
\hline & ${ }^{\mathrm{e}} \mathbf{p}$ & $0.004^{* *}$ & $0.002^{* *}$ & 1.000 & \\
\hline \multicolumn{6}{|c|}{ Onycholysis } \\
\hline \multirow[t]{2}{*}{ Month 0} & Absent & $13(40.6)$ & $13(40.6)$ & $11(34.4)$ & ${ }^{\mathrm{c}} 0.839$ \\
\hline & Present & $19(59.4)$ & $19(59.4)$ & $21(65.6)$ & \\
\hline \multirow[t]{3}{*}{ Month 4} & Absent & $16(50.0)$ & $20(62.5)$ & $11(34.4)$ & ${ }^{\mathrm{c}} 0.079$ \\
\hline & Present & $16(50.0)$ & $12(37.5)$ & $21(65.6)$ & \\
\hline & ${ }^{\mathrm{e}} \mathbf{p}$ & 0.250 & $0.039^{*}$ & 1.000 & \\
\hline \multicolumn{6}{|c|}{ Subungual hyperkeratosis } \\
\hline \multirow[t]{2}{*}{ Month 0} & Absent & $16(50.0)$ & $18(56.3)$ & $16(50.0)$ & ${ }^{\mathrm{c}} 0.846$ \\
\hline & Present & $16(50.0)$ & $14(43.8)$ & $16(50.0)$ & \\
\hline \multirow[t]{3}{*}{ Month 4} & Absent & $23(71.9)$ & $27(84.4)$ & $16(50.0)$ & ${ }^{\mathrm{c}} 0.011^{*}$ \\
\hline & Present & $9(28.1)$ & $5(15.6)$ & $16(50.0)$ & \\
\hline & ${ }^{\mathrm{e}} \mathbf{p}$ & $0.016^{*}$ & $0.004^{* *}$ & 1.000 & \\
\hline
\end{tabular}

cPearson chi-square test, ${ }^{d}$ Fisher- Freeman-Halton test, eMcNemar test, ${ }^{*} p<0.05$, ${ }^{* *} p<0.01$, Mtx: Methotrexate, TA: Triamcinolone acetonite, SP: Serum physiologic significantly higher in nails treated with methotrexate than the nails treated with TA and SP. At month 4, this percentage was similar in nails treated with methotrexate and TA which was higher than those treated with SP (Table 4). Besides, 50\% or more clinical improvement was seen in $62.5 \%(n=20)$ and $46.8 \%$ $(n=15)$ of the patients after methotrexate and TA treatments, respectively. The clinical photograph of a nail (thumb) treated with methotrexate before the study and at month 4 is given in Figure $3 a$ and $b$.

\section{Visual Analog Scale Scores}

The VAS pain scores were statistically similar in different treatment groups at months $1(p=0.780)$ and $4(p=0.393)$. At month 4 , the decrease in the VAS scores was not statistically significant only in nails treated with methotrexate $(p=0.330)$.

\section{Adverse Effects and Relapse Ratios}

The rate of adverse effects statistically significantly differed between the treatment groups at month $1(p=0.001)$. However, adverse effects were similar at month $4(p=0.075)$. At month 1 , the ratio of crust formation was significantly higher in nails treated with methotrexate than the other groups. At month 1 , in the methotrexate group, erythema was seen in 1 patient, crust formation in 5 patients, and petechiae in 2 patients whereas in
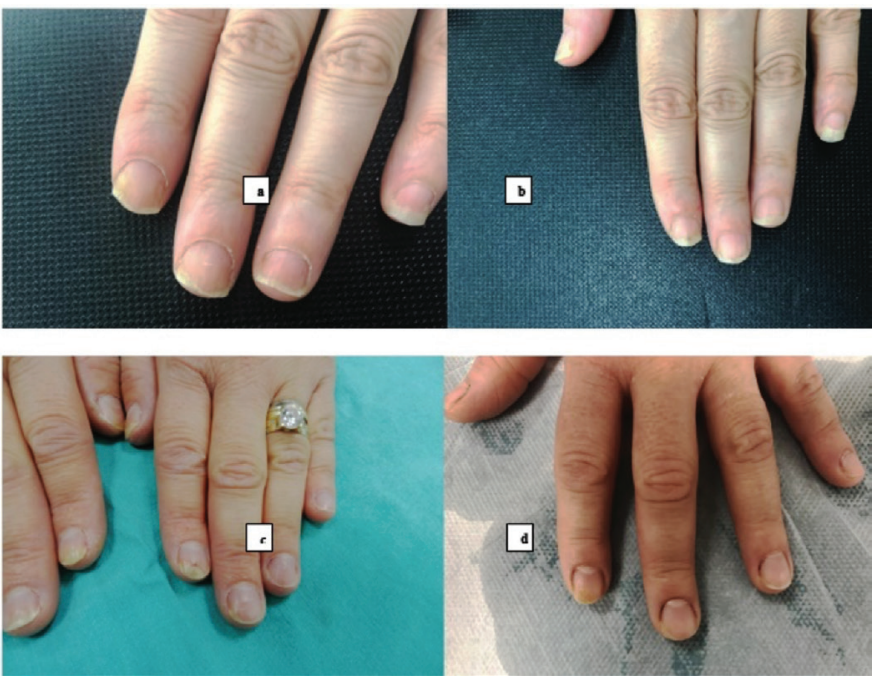

Figure 2: The pre-treatment a) and post-treatment b) photographs of three nails having similar nail area psoriasis severity index scores and signs of nail bed involvement (onycholysis, oil/salmon patches and splinter hemorrhage). The index, middle and ring fingers were randomly assigned to the triamcinolone acetonite (TA), methotrexate and serum physiologic (SP) groups, respectively. Onycholysis significantly decreased in the nail treated with TA and similar signs of oil/salmon patches and splinter hemorrhage in the nails treated with methotrexate and TA at month $4^{\text {th }}$ the pre-treatment c) and post-treatment d) photographs of three nails with similar nail area psoriasis severity index scores and signs of nail matrix involvement (pitting). The index, third and ring fingers were randomly assigned to the methotrexate, TA and SP groups, respectively. Pitting significantly decreased only in the nail treated with methotrexate 
the TA group, atrophy was seen in 2 patients and petechiae in 1 patient. At month 4, erythema (2 patients) and petechiae (1 patient) were recorded in the methotrexate group and atrophy was observed in 2 patients in the TA group. The relapse ratios after methotrexate and TA treatments were similar $(p=0.230)$.

Follow-up Modified Nail Area Psoriasis Severity Index Scores

At the end of the 6 month follow-up 10 patients were lost. After the examination of the 66 nails of the 22 patients the clinical relapse rates were $15 \%, 25 \%$ and $60 \%$ for methotrexate, TA and SP treatment groups.

Table 2: The assessment of the signs of nail matrix involvement according to different treatments

\begin{tabular}{|c|c|c|c|c|c|}
\hline & & \multicolumn{3}{|c|}{ Treatment } & \multirow[t]{2}{*}{$\mathbf{p}$} \\
\hline & & $\begin{array}{l}\text { Mtx } \\
(n=32)\end{array}$ & $\begin{array}{l}\text { TA } \\
(n=32)\end{array}$ & $\begin{array}{l}\text { SP } \\
(n=32)\end{array}$ & \\
\hline \multicolumn{6}{|c|}{ Sign of the nail matrix involvement } \\
\hline \multirow[t]{2}{*}{ Month 0} & Absent & $2(6.3)$ & $3(9.4)$ & $1(3.1)$ & ${ }^{\mathrm{d}} 0.869$ \\
\hline & Present & $30(93.8)$ & $29(90.6)$ & $31(96.9)$ & \\
\hline \multirow[t]{3}{*}{ Month 4} & Absent & $10(31.3)$ & $3(9.4)$ & $1(3.1)$ & ${ }^{\mathrm{d}} 0.008^{* *}$ \\
\hline & Present & $22(68.8)$ & $29(90.6)$ & $31(96.9)$ & \\
\hline & ${ }^{\mathrm{e}} \mathbf{p}$ & $0.008^{* *}$ & 1.000 & 1.000 & \\
\hline \multicolumn{6}{|l|}{ Pitting } \\
\hline \multirow[t]{2}{*}{ Month 0} & Absent & $12(37.5)$ & $12(37.5)$ & $8(25.0)$ & ${ }^{\mathrm{c}} 0.472$ \\
\hline & Present & $20(62.5)$ & $20(62.5)$ & $24(75.0)$ & \\
\hline \multirow[t]{3}{*}{ Month 4} & Absent & $24(75.0)$ & $14(43.8)$ & $8(25.0)$ & ${ }^{\mathrm{c}} 0.001^{* *}$ \\
\hline & Present & $8(25.0)$ & 18 (56.3) & $24(75.0)$ & \\
\hline & ${ }^{\mathrm{e}} \mathbf{p}$ & $0.001^{* *}$ & 0.500 & 1.000 & \\
\hline \multicolumn{6}{|c|}{ Leukonychia } \\
\hline \multirow[t]{2}{*}{ Month 0} & Absent & $10(31.3)$ & $12(37.5)$ & $11(34.4)$ & ${ }^{\mathrm{c}} 0.871$ \\
\hline & Present & $22(68.8)$ & $20(62.5)$ & $21(65.6)$ & \\
\hline \multirow[t]{3}{*}{ Month 4} & Absent & $20(62.5)$ & $17(53.1)$ & $11(34.4)$ & ${ }^{c} 0.072$ \\
\hline & Present & $12(37.5)$ & 15 (46.9) & $21(65.6)$ & \\
\hline & ${ }^{\mathrm{e}} \mathbf{p}$ & $0.002^{* *}$ & 0.063 & 1.000 & \\
\hline \multicolumn{6}{|c|}{ Red lunula } \\
\hline \multirow[t]{2}{*}{ Month 0} & Absent & $8(25.0)$ & $9(28.1)$ & $9(28.1)$ & ${ }^{c} 0.949$ \\
\hline & Present & $24(75.0)$ & $23(71.9)$ & $23(71.9)$ & \\
\hline \multirow[t]{3}{*}{ Month 4} & Absent & $26(81.3)$ & $21(65.6)$ & $10(31.3)$ & ${ }^{c} 0.001^{* *}$ \\
\hline & Present & $6(18.8)$ & $11(34.4)$ & $22(68.8)$ & \\
\hline & ${ }^{\mathrm{e}} \mathbf{p}$ & $0.001^{* *}$ & $0.001^{* *}$ & 1.000 & \\
\hline \multicolumn{6}{|c|}{ Onychorrhexis } \\
\hline \multirow[t]{2}{*}{ Month 0} & Absent & $17(53.1)$ & $16(50.0)$ & $16(50.0)$ & ${ }^{c} 0.959$ \\
\hline & Present & $15(46.9)$ & $16(50.0)$ & $16(50.0)$ & \\
\hline \multirow[t]{3}{*}{ Month 4} & Absent & $25(78.1)$ & 23 (71.9) & $16(50.0)$ & ${ }^{c} 0.043^{*}$ \\
\hline & Present & 7 (21.9) & $9(28.1)$ & $16(50.0)$ & \\
\hline & ${ }^{\mathrm{e}} \mathbf{p}$ & $0.008^{* *}$ & $0.016^{*}$ & 1.000 & \\
\hline
\end{tabular}

'Pearson chi-square test, ${ }^{d}$ Fisher- Freeman-Halton test, ${ }^{e}$ McNemar test, ${ }^{*} p<0.05$,

${ }^{* *} p<0.01$, Mtx: Methotrexate, TA: Triamcinolone acetonite, SP: Serum physiologic

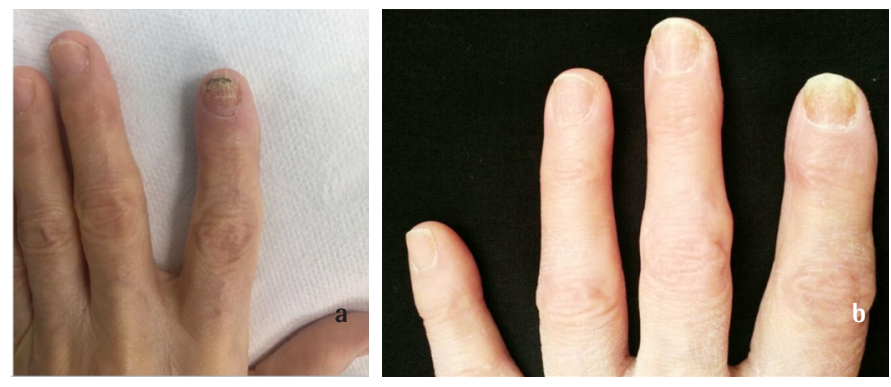

Figure 3: The clinical photograph of a nail (thumb) treated with methotrexate a-before the study and b-at month 4

\section{Discussion}

Today, it is generally recommended to consider nail psoriasis separately for nail matrix and nail bed abnormalities $(1,17)$. When the signs of nail matrix psoriasis are evident, topical or intralesional treatment should be applied to the proximal nail folds and if the nail bed is involved, it should be ensured that the drug is absorbed into the inflamed nail bed tissue (1). This study also showed the changes in the clinical signs of the nail matrix and nail bed involvements separately to discuss the individual efficacy of each treatment in an objective manner. In our study, we performed the injection into four separate points; two into the nail fold (just above the nail matrix) and two into the distal medial and lateral nail folds to allow the absorption of the drug into both the nail matrix and bed. Studies have demonstrated that the clinical efficacy and remission duration of intralesional corticosteroids are highly variable (3-8). Intralesional injection of corticosteroids into the nail bed and matrix has been shown to be effective especially for the signs of nail matrix involvement accompanied with partial or moderate responses in the signs of nail bed involvement (2). However, the injection technique targeting the nail matrix has no effect on the signs of nail bed involvement. Higher concentrations of TA $(10 \mathrm{mg} / \mathrm{mL})$ is commonly recommended for 6-12 injections at one-month intervals followed by further sessions at longer (two-month) intervals (17). This modified regimen also includes injection into four periungual sites and is able to symmetrically deliver the steroid into the nail matrix and nail bed. In recent clinical studies, better clinical results have also been reported for nail bed psoriasis $(2,17)$. In our study, the number of the sessions was lower compared to previous studies but a higher concentration of TA was used and the interval between each session was three weeks. The clinical studies on intralesional corticosteroids for nail psoriasis have revealed similar results. For example, Saleem and Azim (8) reported clinical improvement especially in the signs of nail matrix involvement after $0.1 \mathrm{~mL}$ of $10 \mathrm{mg} / \mathrm{mL} \mathrm{TA}$ was injected into four points of the nail matrix and bed once or twice in 35 patients. Remarkable clinical improvements were $71 \%$ in pitting, $58 \%$ in ridging and $18 \%$ in thickening. Among 
the signs of nail bed involvement, relatively lower improvement was observed; $37 \%$ in onycholysis and $57 \%$ in subungual hyperkeratosis (8). In another study conducted with 17 patients

Table 3: Clinician's assessment scores according to different treatment groups

\begin{tabular}{|c|c|c|c|c|c|}
\hline & \multicolumn{3}{|c|}{ Treatment } & \multirow[t]{2}{*}{$\mathbf{p}$} \\
\hline & & $\begin{array}{l}\text { Mtx } \\
(n=32)\end{array}$ & $\begin{array}{l}\text { TA } \\
(n=32)\end{array}$ & $\begin{array}{l}S P \\
(n=32)\end{array}$ & \\
\hline \multicolumn{6}{|c|}{ Clinician's assessment } \\
\hline \multirow[t]{5}{*}{ Month 1} & Very bad & $15(46.9)$ & $23(71.9)$ & $30(93.8)$ & $0.001^{* *}$ \\
\hline & Bad & $10(31.3)$ & $7(21.9)$ & $1(3.1)$ & \\
\hline & Good & $5(15.6)$ & $2(6.3)$ & $0(0)$ & \\
\hline & Very good & $2(6.3)$ & $0(0)$ & $1(3.1)$ & \\
\hline & $\begin{array}{l}\text { Min-Max } \\
\text { (Median) }\end{array}$ & $1-4(2)$ & $1-3(1)$ & $1-4(1)$ & \\
\hline \multirow[t]{6}{*}{ Month 4} & Very bad & $4(12.5)$ & $3(9.4)$ & 30 (93.8) & $0.001^{* *}$ \\
\hline & Bad & $4(12.5)$ & $7(21.9)$ & $0(0)$ & \\
\hline & Good & $9(28.1)$ & $9(28.1)$ & $1(3.1)$ & \\
\hline & Very good & $15(46.9)$ & $13(40.6)$ & $1(3.1)$ & \\
\hline & $\begin{array}{l}\text { Min-Max } \\
\text { (Median) }\end{array}$ & $1-4(3)$ & $1-4(3)$ & $1-4(1)$ & \\
\hline & $\mathbf{p}$ & $0.001^{* *}$ & $0.001^{* *}$ & 1.000 & \\
\hline
\end{tabular}

${ }^{* *} p<0.01$, Mtx: Methotrexate, TA: Triamcinolone acetonite, SP: Serum physiologic

Table 4: Patient satisfaction scores according to different treatments

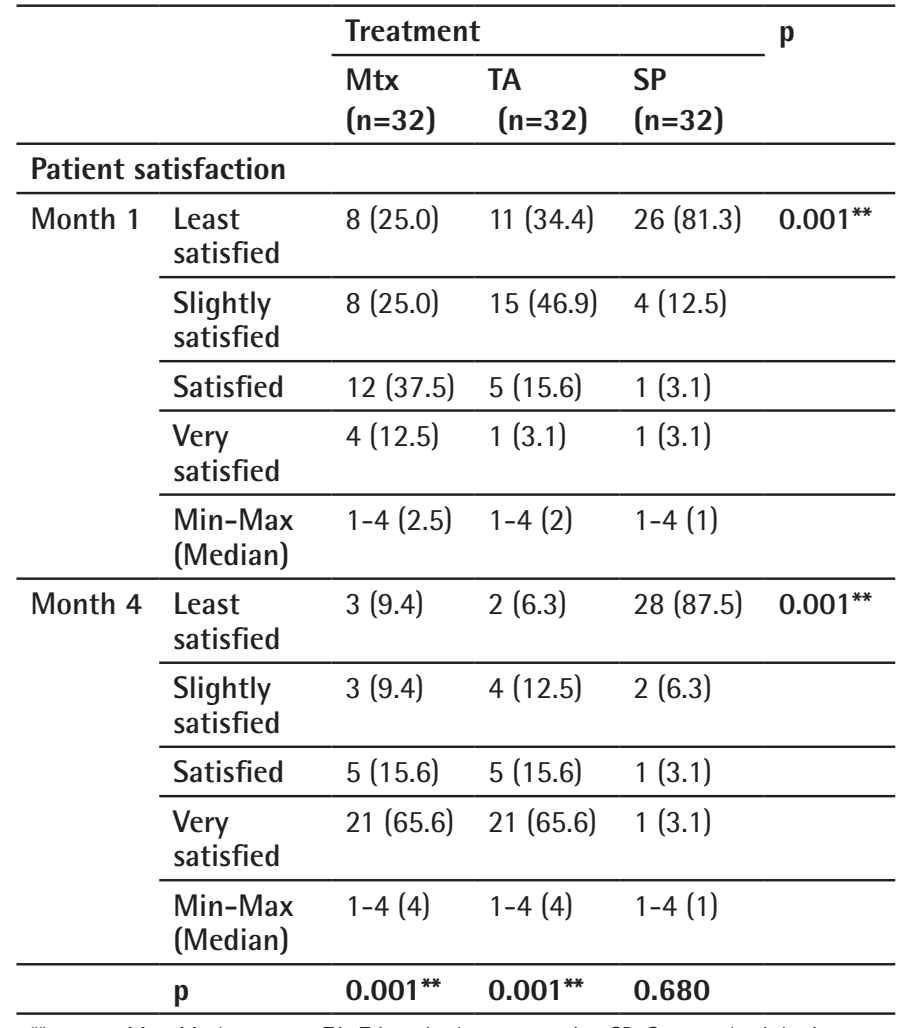

${ }^{* *} p<0.01$, Mtx: Methotrexate. TA: Triamcinolone acetonite, SP: Serum physiologic with nail psoriasis, $0.07 \mathrm{~mL}$ of $8 \mathrm{mg} / \mathrm{mL}$ TA was administered into the proximal nail folds every four weeks and $46 \%$ reduction was noted in the mean target-NAPSI scores (5). While the nail matrix target-NAPSI score decreased by $50 \%$, the nail bed target-NAPSI score decreased only by $38 \%$ (5). Onycholysis was also previously reported to be the most treatment-resistant nail finding in contrast to the results obtained from the current study (18). Methotrexate is a folic acid analog that combines dihydrofolate reductase and reduces the synthesis of thymidylate, purine and cell proliferation (19). It has also anti-inflammatory effects, as it decreases the production of inflammatory cytokines such as interleukin (IL)-1, interferon-gamma and tumor necrosis factoralpha and it inhibits neutrophil chemotaxis (20). Methotrexate has also anti-mitotic activities and it causes a decrease in the epidermal proliferation of the abnormal nail matrix cells $(19,20)$. We believe that methotrexate mostly acts on the nail matrix and has an inhibitory role on the reproduction of the matrix tissue. In previous studies comparing the efficacy of the systemic forms of methotrexate and cyclosporine, the methotrexate group showed a significant improvement only in the nail matrix scores while the cyclosporine group showed significant improvement only in the nail bed scores (9). The intralesional use of methotrexate may reduce the side effects by limiting the dose but is not a generally accepted treatment for nail psoriasis. In our study, we used a notably higher concentration of methotrexate than a previously reported case treated with $2.5 \mathrm{mg} / \mathrm{mL}$ methotrexate (10). Similar to the current study, in the previously reported case, both pitting and subungual hyperkeratosis improved after six weekly treatments (10). There is only one published article, which has shown significant clinical improvement of nail psoriasis after intralesional methotrexate injection (11). In that study, $0.1 \mathrm{~mL}$ of $25 \mathrm{mg} / \mathrm{mL}$ methotrexate was injected into 30 nail beds of four patients with psoriasis at three-week intervals (11). The decline in the mean NAPSI (from 4.87 to 2.17) was statistically significant. The authors concluded that the injection of methotrexate into the nail bed was effective for the management of nail psoriasis (11). In the current study, we used a lower concentration of methotrexate $(10 \mathrm{mg} / \mathrm{mL})$ and made injections either into the the nail matrix via the proximal nail folds or into the nail bed through the distal nail folds or both. To our knowledge, this is the first study that compared the efficacy of intralesional injection of conventional anti-psoriatic drugs, methotrexate and TA, for fingernail psoriasis. Side effects reported after the intralesional steroid procedures include short-term paresthesia, focal pain, hematoma formation, loss of the nail plate, reversible nail-fold atrophy and rupture of the extensor tendon (3-7). In our study, in addition to the two patients that developed temporary atrophy of the proximal nail fold after TA treatment, petechia, erythema and crusting were seen in nails treated with methotrexate, which all improved in a 
few months after the injection. Although we did not encounter any serious or irreversible adverse effects such as necrosis or persistent atrophy, the periungual petechiae were similar to nail bed hemorrhages that were previously reported (11).

\section{Conclusion}

In this study, 3 nails in the methotrexate group and 6 nails in TA showed no change or worsened whereas 8 nails in the methotrexate group and 2 nails in TA showed an almost complete or complete improvement. Furthermore, 50\% or more clinical improvement was seen in 62.5\% $(n=20)$ and $46.8 \%(n=15)$ of the patients after methotrexate and TA treatments, respectively. We conclude that methotrexate has a beneficial role, especially in the improvement of the signs of nail matrix involvement; such as pitting, leukonychia and onychorrhexis, and corticosteroids improve the signs of the nail bed involvement including subungual hyperkeratosis and onycholysis. Methotrexate may be a better choice for nail psoriasis with the signs of nail matrix involvement and TA for the signs of both nail matrix and nail bed involvements. The most important treatment limitation of intralesional application is the pain especially seen during the distal nail fold injection. Thus, it is mainly indicated for patients with mild to moderate nail psoriasis and in cases where only a few nails are involved. We believe that further randomized comparative clinical studies including different combinations of intralesional treatments such as methotrexate, corticosteroids, cyclosporine, and biological agents via different techniques are needed to reveal evidence-based clinical data on the intralesional treatment of nail psoriasis.

\section{Ethics}

Ethics Committee Approval: This study was approved by the İstanbul Medipol University Faculty of Medicine Ethics Committee (66291034-604.01.01-E.2043).

Informed Consent: All patients were given written informed consent before the study.

\section{Authorship Contributions}

Surgical and Medical Practices: P.Ü., Concept: Pelin Üstüner, A.B., Design: P.Ü., Data Collection or Processing: P.Ü., A.B., Analysis or Interpretation: P.Ü., A.B., M.Ö., Literature Search: P.Ü., A.B., Writing: P.Ü.
Conflict of Interest: No conflict of interest was declared by the authors.

Financial Disclosure: The authors declared that this study received no financial support.

\section{References}

1. Tan ES, Chong WS, Tey HL. Nail psoriasis: a review. Am J Clin Dermatol 2012;13:375-388.

2. Klaassen KM, van de Kerkhof PC, Bastiaens MT, et al. Scoring nail psoriasis. J Am Acad Dermatol 2014;70:1061-1066.

3. Pasch MC. Nail Psoriasis: A Review of Treatment Options. Drugs 2016;76:675705.

4. de Berker DA, Lawrence CM. A simplified protocol of steroid injection for psoriatic nail dystrophy. Br J Dermatol 1998;138:90-95.

5. Nantel-Battista M, Richer V, Marcil I, et al. Treatment of nail psoriasis with intralesional triamcinolone acetonide using a needle-free jet injector: a prospective trial. J Cutan Med Surg 2014;18:38-42.

6. Grover $\mathrm{C}$, Bansal $\mathrm{S}$, Nanda $\mathrm{S}$, et al. Efficacy of triamcinolone acetonide in various acquired nail dystrophies. J Dermatol 2005;32:963-968.

7. Khoo BP, Giam YC. A pilot study on the role of intralesional triamcinolone acetonide in the treatment of pitted nails in children. Singapore Med J 2000;41:66-68.

8. Saleem K, Azim W. Treatment of nail psoriasis with a modified regimen of steroid injections. J Coll Physicians Surg Pak 2008;18:78-81.

9. Gümüşel M, Özdemir M, Mevlitoğlu I, et al. Evaluation of the efficacy of methotrexate and cyclosporine therapies on psoriatic nails: a one-blind, randomized study. J Eur Acad Dermatol Venereol 2011;25:1080-1084.

10. Sarıcaoglu $\mathrm{H}, \mathrm{Oz} A$, Turan $\mathrm{H}$. Nail psoriasis successfully treated with intralesional methotrexate: case report. Dermatology 2011;222:5-7.

11. Daulatabad D, Grover C, Singal A. Role of nail bed methotrexate injections in isolated nail psoriasis: conventional drug via an unconventional route. Clin Exp Dermatol 2017.

12. Grover $\mathrm{C}$, Bansal $\mathrm{S}$, Nanda $\mathrm{S}$, et al. Efficacy of triamcinolone acetonide in various acquired nail dystrophies. J Dermatol 2005;32:963-968.

13. de Berker D. Management of psoriatic nail disease. Semin Cutan Med Surg 2009;28:39-43.

14. Garzitto A, Ricceri F, Tripo $L$, et al. Possible reconsideration of the Nail Psoriasis Severity Index (NAPSI) score. J Am Acad Dermatol 2013;69:10531054.

15. Rich P, Scher RK. Nail Psoriasis Severity Index: a useful tool for evaluation of nail psoriasis. J Am Acad Dermatol 2003;49:206-212.

16. Parrish CA, Sobera JO, Elewski BE. Modification of the Nail Psoriasis Severity Index. J Am Acad Dermatol 2005;53:745-746.

17. Oram Y, Akkaya AD. Treatment of nail psoriasis: common concepts and new trends. Dermatol Res Pract 2013;2013:180496.

18. Peachey RD, Pye RJ, Harman RR. The treatment of psoriatic nail dystrophy with intradermal steroid injections. Br J Dermatol 1976;95:75-78.

19. Hagner N, Joerger M. Cancer chemotherapy: targeting folic acid synthesis. Cancer Manag Res 2010;2:293-301.

20. Chan ES, Cronstein BN. Methotrexate--how does it really work? Nat Rev Rheumatol 2010;6:175-178. 